\title{
CITIES WITH COUNTY RIGHTS AS CARRIERS OF INNOVATIONAL POTENTIAL
}

\section{A MEGYEI JOGÚ VÁROSOK, MINT INNOVÁCIÓS POTENCIÁL HORDOZÓK}

Judit BERKES, PhD student

Széchenyi István University, Doctoral School for Regional Economic Sciences

Address: $\quad 9026$ Győr, Egyetem tér 1.

Phone: $\quad+3696503400 / 3819$

E-mail: berkes.judit@sze.hu 


\title{
A MEGYEI JOGÚ VÁROSOK, MINT INNOVÁCIÓS POTENCIÁL HORDOZÓK
}

\author{
CITIES WITH COUNTY RIGHTS AS CARRIERS OF \\ INNOVATIONAL POTENTIAL
}

Keywords: city network, innovational potential, cities with county rights, competitiveness, spatial structure

\begin{abstract}
The examination of cities' innovational potential has been in the focus of attention for regional studies, however, there are only a few researches that carried out a complex examination that would embrace the entire Hungarian city-network. The exploratory examination of cities' success is determinative, since in the competitive situations characteristic of today's world, strategies well-developed for results could serve to better their position, although it is not only science seeking for answers but politics as well, for the strengthening of their position is an important task. The basis for our study is an examination carried out in 2005, whose methodology we kept, only the variables that were considered irrelevant in this study were modified. The Hungarian city-network has formed and changed during this time; there are some settlements that could actually keep their central role, however, there are also examples that certain cities could not reach such a level of development that they would be added to the 23 outstanding ones. The examination made it possible to explore the differences within the Hungarian city-networks, as well as to shed light to the degree of innovational capabilities of the well-confinable groups of city-networks. The results show that the difference between the separate groups is increasing, but the differences between cities that belong together is decreasing. It is important to highlight that in the case of the cities performing excellent compared to the Hungarian settlements' average achievement, the innovational and economic potential mostly do not meet, except in the case of a few cities with outstanding results.
\end{abstract}

Kulcsszavak: városhálózat, innovációs potenciál, megyei jogú városok, versenyképesség, térszerkezet

\begin{abstract}
Absztrakt
A városok innovációs potenciáljának vizsgálata a regionális tudomány fókuszában áll, azonban összetett, a magyarországi városok egész hálózatára kiterjedő kutatást kevesen végeztek. A városok sikerességének feltáró vizsgálata meghatározó, hiszen a mai világra jellemző versenyhelyzetben az eredményekre megfelelően kidolgozott stratégiák a pozíciójuk javítását szolgálhatják, azonban nem csak a tudomány keresi a válaszokat, hanem a politika is, hiszen fontos feladat a pozíciójuk javítása. A vizsgálat alapját egy 2005 -ben lezajlott kutatás jelenti, melynek módszertanát megtartottuk, csak a jelen vizsgálatban irrelevánsnak számító változókon módosítottunk. A magyar városhálózat ez alatt az idő alatt formálódott, alakult; vannak olyan települések, amelyek megtartották központi szerepüket, azonban láthatunk arra is példát, hogy bizonyos nem sikerült olyan fejlettségi szintet elérni, amely által bekerülhettek volna a kiugró 23 város közé. A vizsgálat lehetőséget adott arra, hogy felderítsük a magyar városhálózatban jelen lévő differenciákat, illetve feltárjuk az alapvető jellemzőik alapján jól körülhatárolható városok csoportjait, illetve innovációs képességük mértékét. A kapott eredmények azt mutatják, hogy a körülhatárolt csoportok közötti különbség növekszik, azonban az összetartozó városok között mérséklődnek az eltérések. Fontos kiemelni azt is, hogy a magyar települések átlagos teljesítményéhez képest kiválóan teljesítỏ városok esetében az innovációs és a gazdasági potenciál többnyire nem találkozik egymással, kivéve néhány kimagasló eredményekkel rendelkező város esetében.
\end{abstract}




\section{BEVEZETÉS}

A városok sikerességének mértékét és azok okait sok hazai városkutató vizsgálta már (Enyedi, Rechnitzer, Lengyel, Nemes Nagy, Csapó, Smahó, Szirmai, Velkey, Izsák, Barsi, Csizmadia, stb.), azonban komplex, az egész városhálózatra kiterjedő elemzésről kevés szakirodalom számol be. A városok sikerességének feltáró vizsgálata meghatározó, hiszen a mai világra jellemző versenyhelyzetben az eredményekre megfelelően kidolgozott stratégia a pozíciójuk javítását szolgálhatják, azonban nem csak a tudomány keresi a válaszokat, hanem a politika is, hiszen fontos feladat a pozíciójuk javítása.

Míg 1990-ben 164 városi jogállású település létezett Magyarországon, mára ezek az adatok megduplázódtak, hiszen jelenleg 348 város van.

\section{KUTATÁSI ELŐZMÉNYEK, CÉLKITÜZÉS}

A magyarországi városhálózat a 90-es években átrendeződött, melynek következményeként az első években erős hatást gyakorolt az intézményi ellátottság, illetve a tradicionális gazdaság, viszont az ezredfordulóhoz érve az üzleti szolgáltatók és a gazdaság kapott döntő szerepet. Felértékelődött a tudás, illetve az ezt közvetítő intézmények tevékenysége.

Ezekre az eredményekre felfigyelve készült el Grosz - Rechnitzer (2005) által publikált ${ }^{44}$ innovációs potenciál-vizsgálat, amely magára a hálózatra, illetve a fejlődésben megjelenő új elemekre mutatott rá. Körvonalazódott, hogy a humán erőforrásbázis jelenthet a megújító erőt. Ez a vizsgálat a városhálózat tudásalapú innovációs rendszereit gyüjtötte össze és vizsgálta meg.

Célunk kettős, egyrészt megismerni a települések megújulási formáit egy - az előző kutatásban kidolgozott - modell alapján: feltárni az anyagi-tárgyi determináns faktorokat (intézményrendszer, foglalkoztatottság, munkanélküliség, gazdasági fejlettség), továbbá a humán erőforrás kiaknázatlan lehetőségeit, illetve az innovatív magatartás lokális formáit, melynek feltétele a megfelelő intézményi háttér (szabadalmi bejelentések száma, $\mathrm{K}+\mathrm{F}$ szektor adatai, stb.)

Másrészt célunk a 2005-ben publikált kutatás eredményeivel való összehasonlítás, következtetések levonása, hiszen a két empirikus feltérképezés lehetővé teszi a városokban megfigyelhető megújulási képesség folyamatának specifikus értékelését.

\footnotetext{
${ }^{44}$ A jelzett kutatásban az elemzéseket Csizmadia Zoltán végezte a városhálózat egészére és a megyei jogú városokra Nárai Márta.
} 


\section{A VIZSGÁlAT MÓDSZERTANA}

Az előző vizsgálat módszertanát reprodukálva az egyedi változókból öt főkomponens kialakítása történt meg, melynek mutatórendszere az előző vizsgálathoz képest megtartotta stabilitását. Ez arra enged következtetni, hogy a társadalmi-gazdasági folyamatok változatásai ellenére a városhálózat struktúrája alapvetően nem alakult át. Fontos megjegyezni, hogy a dimenziók kialakításánál 327 város adatait vettük figyelembe, amelyben nem szerepeltek a 2013 júniusában várossá nyilvánított települések, valamint Budapest sem. A fökomponens pontszámok olyan standardizált mutatók, melyek lehetőséget adnak az egyes dimenziók tipizálására.

Hasonlóan az előzőekhez: elsőként az innovációs klaszterek kialakítása történt meg, ún. főkomponens-elemzéssel (az innováció szempontjából relevánsnak minősülő adatbázisok azonos dimenzióba tartozó változókat sürít magas megtartott magyarázóértékekkel).

A jelenlegi vizsgálat sem dolgozott megyei jogú városokkal, hanem a teljes városhálózaton lefuttatott átlagalapú klaszterelemzés alapján válogatta le azt a 23 kiugró teljesítményü várost, amelyek kiemelkedő teljesítményt mutatnak és további hierarchikus klaszterképző módszerrel, illetve a teljes modell főkomponens-pontszámainak megtartásával újabb eredményeket mutat. A kiugró 23 település típusát tekintve - néhány kivétellel - megyei jogú város. Ezen kívül bekerült néhány a főváros agglomerációjához tartozó város is, illetve néhány bizonyos szempontok alapján kiemelkedően jól teljesítő város.

Abban az esetben, ha a különböző főkomponensek alapján megpróbáljuk leválasztani az elit városokat (a leggyengébbek nélkül), a megyei jogú városok és Budapest agglomerációja -, amely erős gazdasági potenciállal rendelkezik - minden valószínűség szerint egy klasztert fognak alkotni. Ez alól Gödöllő a kivétel, amely kissé kétoldalú város, tekinthetnénk rá agglomerációként is, hiszen oda tartozik, de elsősorban az egyetem miatt került be ebbe a kategóriába. Így került be Gyöngyös is, illetve a korábbi vizsgálatban Keszthely is). A magyar városhálózat rendelkezik egy ilyen elit réteggel. Mivel a kiugró 23 település jelentősen lefedi a megyei jogú városokat, ezért most csak ezeket kívánom kiemelni.

A jelenleg zajló kutatáson is elvégeztük ezt a módszert, amely egy próba kiértékelésnek felel meg. Ezek alapján 25 várost kaptunk, amely tartalmazta Dunaújvárost és bekerült Vác és Dunakeszi is Budakeszi helyett. A megyei jogú városok közül Hódmezővásárhely és Érd nem került be ebbe a kategóriába. 


\subsection{A FŐKOMPONENSEK RÖVID JELLEMZÉSE}

A gazdasági dimenzió magába foglalja a lakosság, a gazdaság szereplőinek, az ebben érintett intézményeknek, a foglalkoztatottság adatait, illetve a működő vállalkozásokra vonatkozó mutatókat.

A társadalmi aktivitás a választásokon való részvétel mutatóit, a civil társadalom szervezeti hátterét, illetve a társadalmi nyilvánossággal kapcsolatos adatokat tartalmazza.

Az iskolázottság-munkaerőpiac főkomponens a 2011 évi népszámlálás munkaerő-piaci adatait tömöríti magába, tartalmazza a magasan kvalifikált diplomások arányát a népességen belül, különös tekintettel a vezető, értelmiségi foglalkozásúak megoszlására. Itt olyan változókészletet használtunk, amelyet a felsőoktatási intézményi rendszer átalakulása is érintett.

A humánerőforrás dimenzió leginkább a felsőoktatás intézményi és humán állományának súlyát tartalmazza. Ebben nagy szerepet kaptak a vezető oktatókra vonatkozó számadatok, valamint a felsőoktatási karokra vonatkozó adatok.

Az innovációs fökomponens foglalja magába az innovatív tevékenységgel kapcsolatos mutatókat, kezdeményezéseket, valamint ezek támogató, szolgáltató rendszerét, továbbá az információs technológiák használatára vonatkozó adatsorokat is magába sűrít.

\subsection{KLASZTERELEMZÉS EREDMÉNYE}

Az átlagalapú klaszterelemzés módszer segítségével hasonló eredményeket kaptunk, mint 2005-ben publikált kutatásban, viszont látható, hogy az intézmények a jelenléte egyre meghatározóbb.

Hangsúlyos tény, hogy Szeged, Pécs, Debrecen továbbra is fókuszpont, közös tulajdonságuk, hogy felsőoktatási központként funkcionálnak.

Az intézmény alapú humán, innovációs és gazdasági teljesítmény alapján megfigyelhető különbségek még markánsabban jelennek meg. A humán és az innovációs faktorban kiemelkedő mutatószámokkal rendelkező városok gazdasági teljesítménye relatíve gyenge, csak néhány olyan megyei jogú városnál mutatnak jobb eredményeket, amelyek minden faktor esetében gyengén teljesítenek. Ezek alapján azt a legfontosabb következtetést vonhatjuk le, hogy nem találkozik egymással a humán erőforrás és a gazdasági potenciál, amely a későbbiekben komoly strukturális problémát jelenthet. Azokban a városokban, ahol egyébként jelen van a kutatói tudásbázis, megfigyelhető, hogy nem ott helyben nincs lehetősége vagy nem tud érvényesülni, és ez a helyi gazdaság gyengeségével magyarázható. 


\subsection{HIPOTETIKUS KLASZTEREK}

A hierarchikus klaszterezési folyamat során megkapjuk a lehetséges csoportosulási formákat. A csoportok elhatárolásában segítséget nyújthat egy dendrogram készítése, amellyel nyomon lehet követni az összekapcsolódások sorrendjét, illetve az elszakadások pontos helyét (1. ábra)

1. ábra A megyei jogú városok klaszterstruktúrája a tematikus főkomponensek alapján

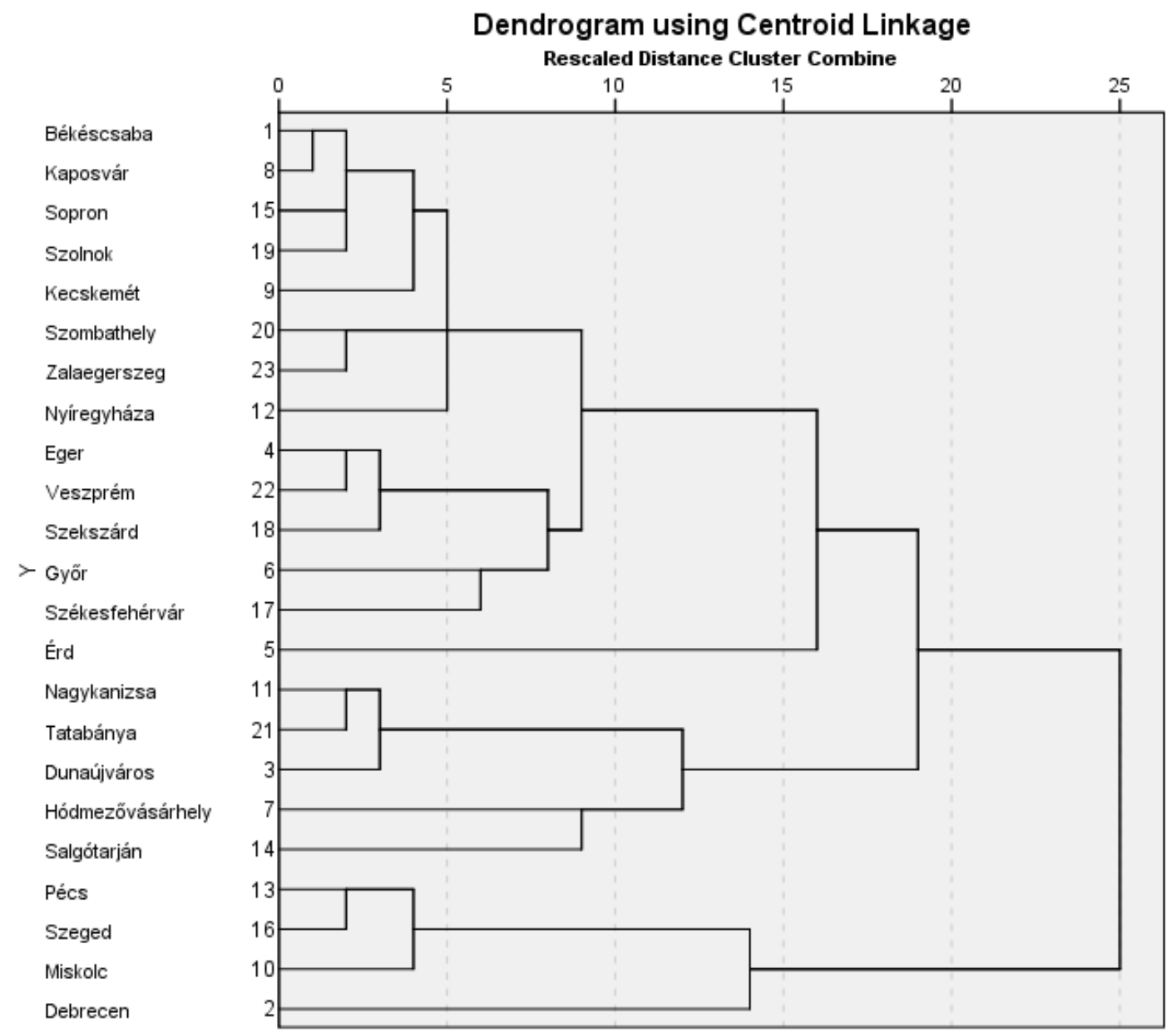

Forrás: Saját szerkesztés

Tehát a következő klasztereket olvashatjuk le az ábráról:

1. táblázat Innovációs klaszterek a megyei jogú városokon belül

\begin{tabular}{|lllll|}
\hline 1. klaszter & 2. klaszter & 3. klaszter & 4. klaszter & 5. klaszter \\
\hline 4 & Győr & Eger & Békéscsaba & Dunaújváros \\
\hline Pécs & Székesfehérvár & Szekszárd & Kaposvár & Hódmezővásárhely \\
\hline Szeged & & Veszprém & Kecskemét & Salgótarján \\
\hline Miskolc & & Nyíregyháza & Tatabánya \\
\hline \multicolumn{3}{|c}{} & Sopron & \\
\hline & & Szolnok & \\
\hline & & Szombathely \\
\hline
\end{tabular}

Forrás: Saját szerkesztés 
Az első klaszterbe tartozik a magyar városhálózat kiemelkedően teljesítő elitje, amely humán és innováció szempontból jól teljesít. A 2005-ös kutatásban Pécs, Szeged, Debrecen közösen alkotta ezt a csoportot, azonban most csatlakozott hozzájuk Miskolc is. Az iskolázottság és a foglalkoztatás mérőszámai kedvezően alakultak, viszont a gazdasági teljesítmény relatíve gyenge.

A második klasztert Győr és Székesfehérvár alkotja. Erről a csoportról elmondható, hogy az innovációs és humán teljesítmény szempontjából átlag feletti mutatókkal rendelkezik, azonban a felsőoktatási intézmények - ha nem is teljes - hiánya érzékelteti hatását. Alapvetően gazdaságilag - a többi klaszterhez képest - jól teljesítenek.

A harmadik klaszterbe az enyhén átlag felett teljesítő városok tartoznak. Tipikusan az a három megyei jogú város, amely az utóbbi évek során indult viszonylag gyors fejlődésnek: Eger, Szekszárd, Veszprém.

A negyedik klasztert az összességében átlagos mutatókkal rendelkező városok alkotják, középmezőnynek is nevezhetnénk ezt a csoportot. Alapvetően stabilak a mutatóik, de az innováció és a humánerőforrás dimenziók tekintetében valódi súlyponti szerepet nem tudnak betölteni. Eltérő pozícióból közeledtek egymáshoz az elmúlt években. Megállapítható, hogy Nyíregyháza, Szombathely gazdasága visszaesett, illetve Sopron sem jeleskedik kiváló gazdasági potenciállal.

Az ötödik klaszter tagjaira jellemzők a stabilan gyenge mutatók. A valóságban nem lehet tiszta elitként tekinteni rájuk, mert vannak olyan nem megyei jogú, de elit városok, amelyek összességéven sokkal kedvezőbb mutatókkal rendelkeznek. Ilyenek például a főváros agglomerációi, ahol jelentősebb a gazdasági potenciál, illetve a felsőoktatási intézményekkel rendelkező városok is megjelentek ebben a csoportban.

Fontos megjegyezni, hogy Érd alapvetően kilóg ezekből a kategóriákból, hiszen sem intézményrendszerrel, sem vonzáskörzettel nem rendelkezik. A 2005-ös kutatásban Budaörs és Budakeszi töltött be hasonló szerepet, azonban Érd a gazdasági és innovációs mutatói alapján jóval gyengébb, egészen máshogy viselkedik, mint az előzőekben említett két település.

A vizsgálat során kiderült, hogy az első klasztert alkotó négy város között mélyülnek a különbségek, melynek oka felsőoktatási expanzióban keresendő. A hallgatók száma és ezzel a felsőfokú végzettségüek száma ott ugrásszerüen megnő, ahol van egyetem vagy föiskola.

A gazdaság térbeli terjedésére pozitív példát mutat Eger, Veszprém és Szekszárd. Fejlődési tengelyt alkot Hatvan, Gyöngyös és Eger, hasonlóképpen Veszprémhez. 
Szekszárd helyzete kissé speciális, a társadalmi aktivitási faktor magas pontszáma emelte be ebbe a kategóriába.

\section{KÖVETKEZTETÉSEK, TAPASZTALATOK}

A magyar városhálózat elit rétegét alkotó megyei jogú városok erősen polarizáltak. A regionális központok kiemelkedő humánerőforrás és innovációs potenciáljuk miatt jelentik a városhálózat csúcsát, viszont az is elmondható, hogy gyenge gazdasági potenciállal rendelkeznek. Ez a két rendszer továbbra is távol marad egymástól, így a városok müködését a közszolgáltatások és a közintézmények jelenléte biztosítja. Azoknak a városoknak, amelyek viszonylag magas gazdasági mutatókkal rendelkeznek (Székesfehérvár, Győr és Kecskemét), a humán és az iskolázottsági főkomponens pontszámuk alacsony, viszont stabilan jók az iskolázottsági mutatóik, kedvezően alakulnak a foglalkoztatottsági arányszámok is, továbbra sem sikerült bekerülniük a legelitebb szektorba.

A négy dimenzió mentén egyetlen egy várost lehetne kiemelni, amelynek minden tekintetben sikerült az átlaghoz képest jóval eredményesebben teljesítenie, az Debrecen. Az elmúlt tíz év alatt nagy ívü fejlődési pályát írt le, és ha ezt képes megtartani, akkor akár a főváros után a második legnagyobb és egyben legjobban teljesítő városként jellemezhető. E tekintetben hasonlóan sikeresen fejlődő településnek mondható Miskolc, amely a gyenge gazdasági mutatóit az erősödő humánerőforrás és a felsőoktatási központi funkcióján alapuló innovációs potenciáljával kompenzálta.

A gazdaság és az intézményrendszer közötti szakadék egyre nagyobb, látható, hogy mélyül a polarizáció. Ennek oka a '90-es években zajló folyamatokban keresendő, vagyis az országban egyre növekvő külföldi tőke egyenlőtlenül oszlott el, amely az évek során nem egyenlítődött ki.

Továbbá a területi egyenlőtlenség folyamatos növekedése tapasztalható. A klasztereken belüli települések közötti differenciák mérséklődtek, azonban az egyes dimenziók között növekedést mutat. Jellemző az is, hogy nem ott termelnek tudást, ahol hasznosítani tudják. A humán, innovációs dimenziók és a gazdaság között még tovább nőtt a szakadék, a gazdaság és a fejlett intézményrendszer nem találkozik egymással. A vizsgálatunk egyik fő célja, hogy az innovációs potenciál ne csak az intézményrendszeren keresztül próbáljuk megragadni, hanem ott is ahol közvetlen kapcsolatot mutatnak a gazdasággal. 


\title{
SUMMARY
}

The examination of cities' innovational potential has been in the focus of attention for regional studies, however, there are only a few researches that carried out a complex examination that would embrace the entire Hungarian city-network. The exploratory examination of cities' success is determinative, since in the competitive situations characteristic of today's world, strategies well-developed for results could serve to better their position, although it is not only science seeking for answers but politics as well, for the strengthening of their position is an important task. The basis for our study is an examination carried out in 2005, whose methodology we kept, only the variables that were considered irrelevant in this study were modified.

The Hungarian city-network has formed and changed during this time; there are some settlements that could actually keep their central role, however, there are also examples that certain cities could not reach such a level of development that they would be added to the 23 outstanding ones.

The previous methodology is reproduced at the individual variables was created with five main components, which shows the system has maintained stability as compared to the previous research.

The economic dimension includes indicators on population, economic actors in the relevant institutions, employment information, as well as established companies.

Social activity indicators participate in the elections, organizational support for civil society and social data on the public included.

The education-labor market dimension includes the 2011 population census data, contains the percentage of highly qualified graduates in the population, particularly the leading intellectuals distribution. Here is a set of variables was used, which involved the transformation of higher education institutional system.

The human resources dimension includes the weight of most higher education institutions and human population. This played an important role in the figures for the leading trainers and information on the academic faculties.

The main component of innovation includes innovation indicators and initiatives, and their support and service system, and data lines for the use of information technology-related activities include innovative condenses itself.

The indicator system which has maintained stability as compared to the previous investigation. It can be concluded that in spite of the socio-economic processes to changes in the network structure of the city basically has not been transformed. Important information that the dimensions were taken into consideration when creating 327 city data, which were not included in the city in June 2013 declared the settlements, and not Budapest. The principal component scores are standardized indicators that allow the characterization of each dimension.

As in previous research: the first was the creation of innovation clusters, so-called. principal component analysis (variables belonging to the same dimension of innovation relevant qualifying database compresses high explanatory value observed). The present study has developed cities with county rights, but also the entire city network were selected on the basis of executing average based cluster analysis city of 23 outstanding performance are, and other hierarchical clustering method, and the entire model is the principal component scores of keeping the show fresh results. The "23 prominent city group" contains mostly of - with some exceptions - cities with county rights. In addition, this group includes some of the capital city agglomeration as well, and some cities that have outstanding performance in some aspects. In this case, if we try to separate the elite from the different cities of principal components (excluding the weakest), the agglomeration of Budapest and cities with county rights - which has strong economic potential - are likely to create a cluster together.

The ongoing research is also carried out this method, which corresponds to a trial evaluation. On this basis, we got 25 cities that included Dunaújváros and new members are Vác and Dunakeszi, which has been introduced in instead of Budakeszi. The county towns of Hódmezővásárhely and Érd has not been included in this category. The examination made it possible to explore the differences within the Hungarian citynetworks, as well as to shed light to the degree of innovational capabilities of the well-confinable groups of city-networks. The results show that the difference between the separate groups is increasing, but the differences between cities that belong together is decreasing. It is important to highlight that in the case of the cities performing excellent compared to the Hungarian settlements' average achievement, the innovational and economic potential mostly do not meet, except in the case of a few cities with outstanding results.

\section{FELHASZNÁLT IRODALOM}

\author{
Beluszky, P. (1999). Magyarország településföldrajza. Általános rész. Dialóg Campus \\ Kiadó, Budapest.
}


Beluszky, P., Győri, R. (1999). A magyarországi városhálózat és az EU-csatlakozás. In: Tér és Társadalom. 1-2. sz., 1-30 p.

Csapó, T. (2005). A magyar városok településmorfológiája. Savaria University Press Szombathely.

Grosz, A., Rechnitzer, J. (szerk.) (2005). Régiók és nagyvárosok innovációs potenciálja Magyarországon. MTA RKK, Pécs-Győr.

Országos Fejlesztési és Területfejlesztési Koncepció (OFTK), 2013.

Pannon Elemző, Hétfa Elemző Központ, Revita Alapítvány (2013). Városhálózati hatásértékelés. http://www.nfu.hu/download/48146/V\%C3\%A1rosh\%C3\%A11\%C3\%B3zat_\%C3\% A9rt\%C3\%A9kel\%C3\%A9si_jelent\%C3\%A9sx.pdf (letöltve: 2013. december 7. $12: 10)$

Rechnitzer J., Csizmadia Z., Grosz A. (2004). A magyar városhálózat tudás alapú megújító képessége az ezredfordulón. In: Tér és Társadalom, 2. sz., 117-156. p.

Rechnitzer, J., Páthy, Á., Berkes, J. (2014). A városhálózat stabilitása és változása. In: Tér és Társadalom, 2. sz., 105-127. p. 